Ersin Eskiler,

Associate Professor, Sakarya University of Applied Science, Turkey

ORCID ID, 0000-0001-7617-2958

email: eeskiler@gmail.com

Remzi Altunisik,

Professor, Sakarya University, Turkey

ORCID ID, 0000-0001-7934-1841

email: remzialtunisik@gmail.com

Nilgun Sarikaya,

Professor, Sakarya University, Turkey

ORCID ID, 0000-0002-1696-4950

email: nilguns@sakarya.edu.tr

Correspondence author: eeskiler@gmail.com

\title{
THE RELATIONSHIP BETWEEN BRAND ASSOCIATIONS AND FAN BEHAVIOURS FOR FOOTBALL TEAMS
}

Abstract. The intense competition in the sports sector has caused changes in the sports marketing perception of team management. Club managements aim to develop brand relationships, strengthen fan loyalty and manage fan behaviors to establish an emotional bond between club brands and fans for gaining competitive advantage. In this context, the current study aimed to assess the relationships between brand relationships, fan loyalty, and fan behavior in football teams. The survey sample is 503 (293 male, 210 female) respondents. Data were collected from Besiktas Gymnastics Club, Fenerbahce Sports Club, and Galatasaray Sports Club team supporters by face-to-face survey method. The structural equation model was used in the research hypothesis testing. The findings identified no statistically significant effect of the attributes and benefits, defined as team brand associations facets, on fan behaviors. Brand associations had a significant influence on the attitudinal and behavioral loyalty of supporters. Besides, behavioral loyalty was an important determinant of fan behaviors. The results indicated that approximately $68 \%$ of the variance of attitudinal loyalty could be explained by the attributes and benefits of brand associations' facets $\left(R^{2}=.677\right)$. Furthermore, facets of the brand associations accounted for approximately $66 \%$ of behavioral loyalty variance ( $\left.R^{2}=.659\right)$. Both brand associations (attributes and benefits) and fan loyalty (attitudinal and behavior loyalty) facets explained approximately $32 \%$ of the variance in fan behavior $\left(R^{2}=.317\right)$. Consequently, it is important to create strong and competitive brand associations in football teams, independent of sporting achievement, create positive fan behaviors, and support these behaviors. The research results could be useful for sports managers/marketers and theorists to explain and interpret fan behaviors.

Keywords: brand associations, loyalty, behavior, fan behavior, football clubs.

Introduction. In the early 2000's Bauer et al. (2005) pointed out the development of the sports industry with the words «sport is becoming more commercialized, and sports entities have become more professional over the years». The global sports market, which was approximately $€ 380$ billion by 2020 , is estimated to have a compound annual growth rate of $8 \%$ by 2021 (The Business Research Company, 2019; 2020). The global sports market is divided into two parts (spectator and participatory sports). The spectator sports market, which is the focus of this study, constitutes $43.6 \%$ (approximately $€ 166$ billion) of the global sports market. The share of the sports teams and clubs in the spectator sports market is about $72.5 \%$ (approx. $€ 121$ billion). Besides, sports clubs, which are part of today's entertainment industry's changing and competitive structure, strive to increase consumers' entertainment budgets (Giroux et al.,

Cite as: Eskiler, E., Altunisik, R., \& Sarikaya, N. (2021). The Relationship Between Brand Associations and Fan Behaviours for Football Teams. Marketing and Management of Innovations, 3, 32-42.

32 http://doi.org/10.21272/mmi.2021.3-03 
2017). Bauer et al. (2005) argued that sports clubs must act as progressive service providers to compete for success with other entertainment offers. Towards this end, branding and brand value are at the center of marketing efforts to provide a competitive advantage to businesses by affecting consumer (supporter) behaviors. Branding is a powerful and effective communication opportunity that provides advantages, including defending and gaining market share from rivals among marketers and consumers (Su and Tong, 2015). Findings of the marketing literature suggestyв that a superior brand might help separate a sports product/club from other sports clubs or alternative entertainment offers (Mullin et al., 2007). Hence, brand strategy is one of the essential factors in the marketing mix.

Thus, it provides a sustainable competitive advantage by using existing resources more effectively and efficiently in the marketplace (Keller, 1993; 2009). Successful sports club executives and/or marketing managers focus on the concept of branding and brand equity to achieve competitive advantage and to increase the equity of their brands (Ross et al., 2006). A review of the rankings of the most valuable brands in football clubs would indicate that the total brand equity of the top ten clubs in the list is $€ 11,007$ million. Moreover, the clubs, which have won important national and international successes in the past years, are ranked in the top rankings of the most valuable brands (Real Madrid - $€ 1,419$ million, Barcelona $€ 1,413$ million, Manchester United - $€ 1,314$ million) (BrandFinance, 2020). Thus, it is clear that sporting achievement in football is an essential determinant of the club's brand value. However, Gladden and Milne (1999) state that sporting achievement and brand equity in different sports branches (basketball, baseball, and hockey) should be separate structures. Findings indicated that sporting performance and brand equity have a positive and significant effect on club revenues. Another support for this idea comes from the fact that certain clubs (e.g., Manchester City) significantly benefit from brand extensions through the sale of licensed products and sponsorship revenues despite poor or mediocre sporting achievement (core product performance) (Gladden and Funk, 2001). Therefore, the corporate capital, which is the economic criteria, could be separated from sporting achievement, while brand equity provides economic performance independently of sporting achievement (Bauer et al., 2005).

In summary, brand equity offers football clubs, including its stakeholders, a variety of advantages, such as the opportunity to create higher profit margins and differentiate from their competitors, regardless of sporting performance. According to Cobb-Walgren and Donthu (1995), the main source of brand value is consumers. Hence brand value should be evaluated by sports clubs based on individual consumers, i.e., fans. This view is qualified as consumer-based brand equity. Consumer-based brand value could be defined as the additional value created by the brand name in the minds of consumers and added to the product (Farquhar and Equity, 1989).

Keller (2013) stated that «consumer-based brand equity happens in consumers having a high level of awareness and familiarity with the brand and hold a particular strength, favorability, and uniqueness in brand associations» in his/her memory. In low participation decisions where consumers desire to base their preferences on the only familiarity, brand awareness alone is sufficient to create a positive consumer response. However, strength, favorability, and uniqueness play an important role in identifying the different consumer responses to brand equity in many other cases (Keller, 1993; 2013). Creating strong club brands, improving fan engagement, and generating new revenues are essential targets for today's sports management (Lee et al., 2018). As one of the ways of achieving these targets, sports management researchers emphasized the importance of investment in brands and the creation of appropriate brand associations to influence fans. Therefore, researchers have indicated that brand associations should be examined as one of the most important factors for sports clubs. In other words, sports teams/clubs should focus on professional and fan-oriented brand relationship management to compete effectively (regardless of sportive success). The literature survey suggested that loyalty could be built due to the successful management of brand relationships. However, it is seen that there is a limited number of studies focusing on explaining/identifying the effects of brand relationships on fan loyalty. Thus, it points to a gap in the 
existing basic knowledge in the relevant literature. This study investigated the relationship between brand relationships, fan loyalty, and behavior; football team brands and their fans. The research expanded the scholarly works on football (sports) teams' brand relationships, which is a premise. Besides, the importance of the fans' attitudinal loyalty influence on their behavioral loyalty was reinforced. Finally, it is possible to predict fan consumption behaviors (the frequency of watching the match in the stadium and on TV, the habits of following their teams in the media, and whether they purchased a licensed product) due to fan loyalty (attitudinal and behavioral). A prediction has been put forward. Interactions between variables were tested with a conceptual model. The obtained findings were discussed.

Literature Review. The studies of (Aaker and Equity, 1991; Keller, 1993) are utilized as a basis for the studies on determining brand associations in the sports sector. Aaker and Equity (1991) divided brand associations into 11 constituents: product attributes, intangibles, customer benefits, relative price, use/application, user/customer, celebrity/person, lifestyle/personality, product class, competitors, and country/geography. Additionally, Keller (1993) has classified the brand associations in three main dimensions: features (organizational characteristics of the brand), benefits (what the brand refers to consumers as a subjective), and attitudes (consumers' holistic assessments of a brand).

Few studies have focused on brand associations in the sports sector (e.g., Gladden and Funk, 2002; Bauer et al., 2005; Ross et al., 2006; Yıldız, 2016). These studies focused on the conceptualization and measurement of brand associations in sports teams/clubs. Ross et al. (2006) noted that the identification and measurement of brand associations are still in the developmental stage for the sports sector. Gladden and Funk (2002) created the first comprehensive classification of brand associations in professional sports (American football, basketball, baseball, and hockey) according to the global classification by Keller (1993). However, some researchers claimed that many limitations and the validity of Gladden and Funk's (2002) study need to be considered (Ross et al., 2006; Yıldız, 2016).

Among these criticisms, Ross et al. (2006) figured out that brand associations consist of 11 dimensions, as follows «brand mark, rivalry, concessions, social interaction, history of the team, commitment, organizational attributes, non-player personnel, stadium community, team success, and team play» in professional sports. Bauer et al. (2005) conducted the first study of football teams' brand associations with 1236 German football fans. The researchers evaluated the brand associations regarding the strength, favorability, and uniqueness of Keller's (2013) study and the brand image model of Gladden and Funk (2001). They modified the suggested factors to fit the German team sport context (Yıldız, 2016). Thus, the sports team brand associations consist of 2 factors (attitudes and benefits) and 12 indicators (athletic success, star player(s), coach, management, logo, stadium, stadium atmosphere, regional importance, fan identification, the interest of friends and family, nostalgia and escape). Furthermore, Yıldız (2016) revealed the specific brand associations in the Turkish football context. As a result of this study, the brand associations in Turkish football teams are classified into two main dimensions: 1) attributes (success, coach, star player, management, club history, stadium, brand marks) and 2) benefits (escape, fan identification, social interaction). In the light of the explanations, it could be stated that there is a consensus that brand associations have a multi-dimensional structure that the dimensions are identified appear to be very similar. Additionally, it is possible to state that a limited number of studies consider the results of sports club brand associations.

Ross et al. (2006) emphasized that brand associations are significant for increasing brand image, brand awareness, and consumer loyalty. On the other hand, brand loyalty is evaluated due to brand equity (Keller, 1993). Brand loyalty is defined as the core of the brand's equity and a measure of customer loyalty to a brand (Aaker and Equity, 1991). In professional sports, brand loyalty consists of the strength of the connection and commitment between the fan and the club. It attracts and retains consumers (Aaker and Equity, 1991; Kaynak et al., 2008). Keller (2013) drawn attention to the attitudinal dimension of loyalty. The author stated that repurchase intention in attitudinal brand loyalty is necessary but not sufficient. In 
this context, sports brand loyalty consists of positive attitudes and repeat patronage behavior towards a particular team (Mahony et al., 2000). According to Bauer et al. (2008) and Kaynak et al. (2008), it is necessary to consider the behavioral and attitudinal dimensions of loyalty together to comprehensively evaluate/interpret the concept of loyalty. Thus, the attitudinal dimension of loyalty constitutes is the fans' emotional or psychological loyalty levels (attitudinal) to a team. Behavioral loyalty represents the past behavior of the fans (purchase and positive word of mouth) and their future behavioral tendencies (willingness to maintain positive and lasting behavior).

According to Gladden and Funk (2001), brand loyalty ensures a steadier following even with the poor or mediocre core product performance (e.g., after losing the season for the team). Thus, this loyalty provides funds to the team or the club. Sometimes, the team or club could control this funding to compensate player salaries, new stadiums or arenas, etc., and increase revenues. Furthermore, brand loyalty guarantees a steadier following through the broadcast media and charges advertisers of teams for advertising time with consistent ratings. Additionally, brand loyalty enables companies to extend beyond their core product by creating additional revenue by sharing brand extensions or license agreements. High brand loyalty allows the team or club to offer these brand extensions across geographic boundaries (Kaynak et al., 2008). Finally, the most salient characteristic of brand loyalty is customer desire to invest time, energy, money, or other resources into the brand during its purchase or consumption. For instance, customers could select a club for a special brand or communicate with other brand users by formal brand representatives. In this way, they would advise on the club brand and its extensions by sharing their loyalty, positive beliefs, and feelings towards their team with others through their fan groups.

Keller (1993) mentioned that brand equity has an important effect on brand loyalty. Past research reveals that brand value is an important concept. Brand relationships have an important effect on the creation of brand value. In other words, creating a strong and desirable brand and developing good brand relationships is the basis of brand loyalty. Therefore, brand associations are related to brand loyalty. In this study, brand associations are classified into two important dimensions (attributes and benefits). In this context, the successful results in these two dimensions are the main basis for the most positive brand responses, intense and active brand loyalty (Aaker and Equity, 1991; Keller, 2013). Hence, it can be stated that there would be a significant relationship between brand associations (attributes and benefits) and fan loyalty (attitudinal and behavioral). Dick and Basu (1994) stated that if loyalty is evaluated only with behavioral criteria, the factors underlying brand loyalty could not be fully understood. Moreover, behavioral definitions seem insufficient to explain how and why brand loyalty is developed and/or changed (Bandyopadhyay and Martell, 2007; Dick and Basu, 1994; Kaynak et al., 2008; Oliver, 1999). Oliver (1999) suggested that «brand loyalty stages display a learning process that evaluates the association of attitude with behavior».

Srivastava and Kaul (2016), Bandyopadhyay and Martell (2007) reported that attitudinal loyalty leads to behavioral loyalty. Therefore, this study was developed on attitudinal loyalty as a precursor of behavioral loyalty. As a result, it is predicted that loyal behavior is based on attitudinal loyalty. In this case, attitudinal loyalty is expected to mediate the relationship between brand associations (attributes and benefits) and behavioral loyalty. As stated earlier, sports clubs strive to increase their market share of consumers' entertainment expenses (Giroux et al., 2017). The most important way to realize that goal is through management of the brand associations and fan loyalty. According to Keller's (2013) conceptualization of brand associations, a sports club could achieve various goals by building fan loyalty regardless of the team's actual performance. Ultimately, a general judgment is that a loyal customer would spend more than a regular customer. Therefore, fan behavior would be related to attitudinal and behavioral loyalty. As a result, the brand associations affect customers' perceptions of loyalty, which, in turn, affects fan behavior. Figure 1 shows the research model of this study. The core hypothesis of the paper:

$\mathrm{H} 1 \mathrm{a}=$ The brand associations (attributes) effect on fans' perception of attitudinal loyalty. 
$\mathrm{H} 1 \mathrm{~b}=$ The brand associations (benefits) effect on fans' perception of attitudinal loyalty.

$\mathrm{H} 2 \mathrm{a}=$ The brand associations (attributes) effect on fans' perception of behavioral loyalty.

$\mathrm{H} 2 \mathrm{~b}=$ The brand associations (benefits) effect on fans' perception of behavioral loyalty.

$\mathrm{H} 3 \mathrm{a}=$ The brand associations (attributes) effect on fan behavior.

$\mathrm{H} 3 \mathrm{~b}=$ The brand associations (benefits) effect on fan behavior.

H4 = Fans' perception of attitudinal loyalty effects on fans' perception of behavioral loyalty.

$\mathrm{H} 5 \mathrm{a}=$ Fans' perception of attitudinal loyalty effects on fan behavior.

$\mathrm{H} 5 \mathrm{~b}=$ Fans' perception of behavioral loyalty effects on fan behavior.

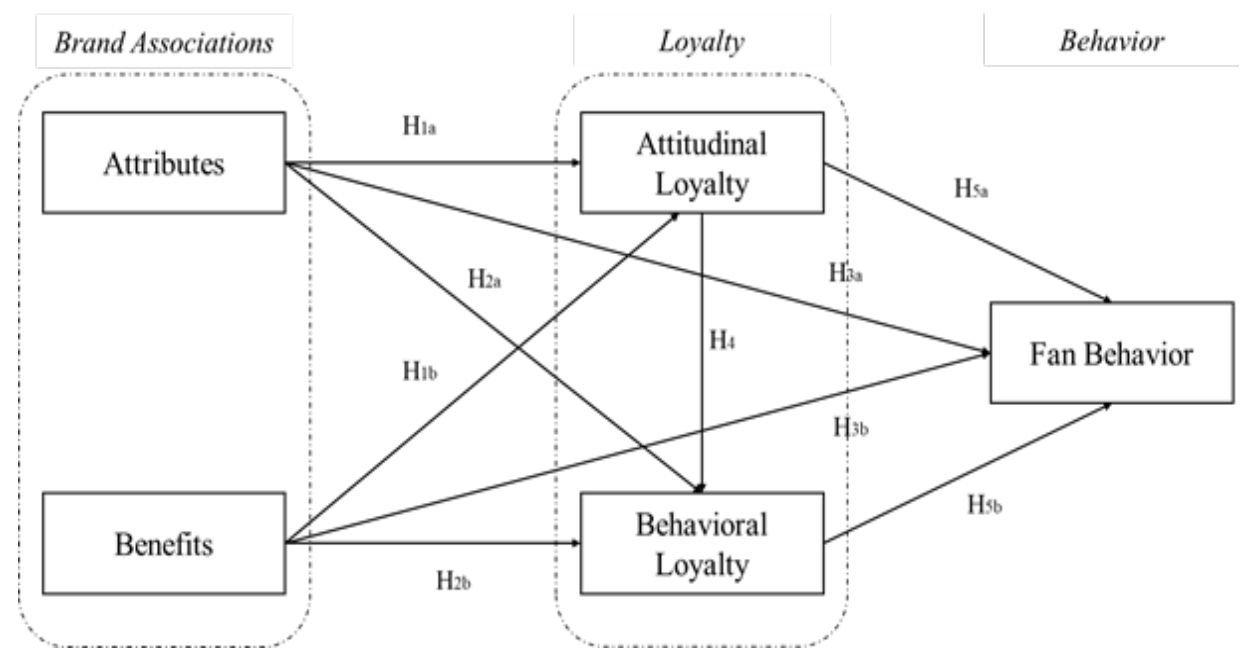

Figure 1. Conceptual model

Sources: developed by the authors.

Methodology and research methods. This study aimed to test interactions between research variables (team brand associations, fan loyalty, and fan behavior) based on a non-experimental, depictive, and descriptive design, which is a quantitative research method.

Data Collection and Sample. This study was performed in the Turkish Super League as the most valuable sixth football league in Europe with total revenue of $€ 734 \mathrm{~m}$ (Barnard et al., 2018). Data were collected from fans of three big Turkish football teams through structured questionnaires administered to respondents personally. These clubs were chosen due to the high level of awareness of the sports service brand in their product categories. Notably, data collection was conducted in the summer break of the Turkish football league (between July and August 2019) to avoid potential short-term response biases affected by relevant the last games. A total of 503 available questionnaires were collected. While the number of male participants was 293 , the number of female participants -210 . The mean age of the participants was $23.43 \pm 7.27$ (range=18-52). The average monthly personal income of the participants was $2.462,00 \pm 1.003,52$. In turn, $41.6 \%, 33.8 \%$, and $24.7 \%$ of the participants supported Galatasaray Sports Club, Fenerbahce Sports Club, and Besiktaş Gymnastics Club, respectively.

Measures. In the current study, the brand association was assessed as two dimensions, including 1) attributes such as success, coach, star player, management, history, stadium, and brandmark, and 2) benefits - escape, fan identification, and social interaction with 33 items brand associations scale. The scale was developed by Yıldız (2016) according to Gladden and Funk's (2002) Team Association Scale- 
TAS and Ross et al.'s (2006) Team Brand Association Scale-TBAS scales. The scale was used in the Turkish football context and provided detailed examinations of factors that impacted brand associations.

Fan loyalty includes attitudinal and behavioral loyalty dimensions (Bauer et al., 2008; Gladden and Funk, 2001). In turn, 14 items adapted from Bauer et al. (2008) were used to determine fans' attitudinal and behavioral loyalty levels. There were eight items and six items that measured attitudinal and behavioral loyalty, respectively, on the scale.

A 7-point Likert scale (ranging from strongly disagree (1) to strongly agree) was used to measure all items under the brand associations and loyalty scales (7). Table 1 summarizes descriptive statistics and correlation values of scales. Moreover, fan behavior was measured by evaluating the frequency of watching the match in the stadium and on TV, the habits of following their teams in the media, and whether they purchased a licensed product (Funk et al., 2009; Funk and James, 2006). Finally, demographic questions included age, gender, supported team, and income. Furthermore, two items in the questionnaire were used to test reading the questions by respondents and answered randomly. The questionnaire was excluded from the analysis if the respondents did not respond correctly to the two items.

Data analysis. SPSS (Statistical Package for the Social Sciences) and AMOS (Analysis of Moment Structure) v.20 were used for the data analysis. Descriptive statistics were performed to determine the participants' profiles and data normality. The skewness and kurtosis values were controlled for normality by meeting the criterion of being between -2 and +2 (George and Mallery, 2016). In addition to the reliability analysis of the Cronbach coefficient, Pearson correlation analysis was also performed to determine the relationships between variables. Finally, SEM was conducted with Amos to analyze the hypotheses of this study (Byrne, 2010; Kline, 2015).

Results. The result indicated that the mean of the data was $5.14 \pm 1.12,4.88 \pm 1.18,5.34 \pm 1.54$, and $4.62 \pm 1.64$ for attributes, benefits, attitudinal loyalty, and behavioral loyalty, respectively. All the mean scores were a considerable extent. The correlation matrix revealed a reasonable discriminant validity with all correlation coefficients below $r<.85$ benchmark (Kline, 2015). Moreover, the scales resulted in an alpha score ranging from 0.923 to 0.834 . Thus, they were considered acceptable (George and Mallery, 2016; Tabachnick and Fidell, 2007). Table 1 summarizes descriptive statistics for each scale used in the study.

Table 1. Descriptive statistics and correlations among variables

\begin{tabular}{lccccc}
\hline \multicolumn{1}{c}{ Factors } & Mean & SD. & $\alpha$ & Attitudinal loyalty & Behavioral loyalty \\
\hline Attributes & 5.14 & 1.12 & $\begin{array}{c}0.89 \\
6\end{array}$ & $0.777^{* *}$ & $0.669^{* *}$ \\
Benefits & 4.88 & 1.18 & $\begin{array}{c}0.83 \\
4\end{array}$ & $0.799^{* *}$ & $0.793^{* *}$ \\
Attitudinal loyalty & 5.34 & 1.54 & $\begin{array}{c}0.92 \\
3\end{array}$ & 1 & $0.730^{* *}$ \\
Behavioral loyalty & 4.62 & 1.64 & $\begin{array}{c}0.89 \\
8\end{array}$ & & 1 \\
\hline
\end{tabular}

7-point Likert scale. 1= strongly disagree, 7= strongly agree $\quad{ }^{* *}: p<0.01 ; N=503$

Note: Abbreviations: $\mathrm{SD}=$ Standard Deviations. $\alpha=$ Cronbach's alpha

Sources: developed by the authors.

Structural equation modeling (SEM) was performed to test the hypotheses. In figure 2, a good fit to the data was obtained by the hypothesized structural model. The results of goodness-of-fit tests showed satisfactory model fit according to generally accepted standards ( $\mathrm{x}^{2} / \mathrm{df}=1.46, \mathrm{TLI}=.99, \mathrm{CFI}=.99, \mathrm{GFI}=.98$, RMSEA=.030) (Byrne, 2010; Kline, 2015; Tabachnick and Fidell, 2007). 


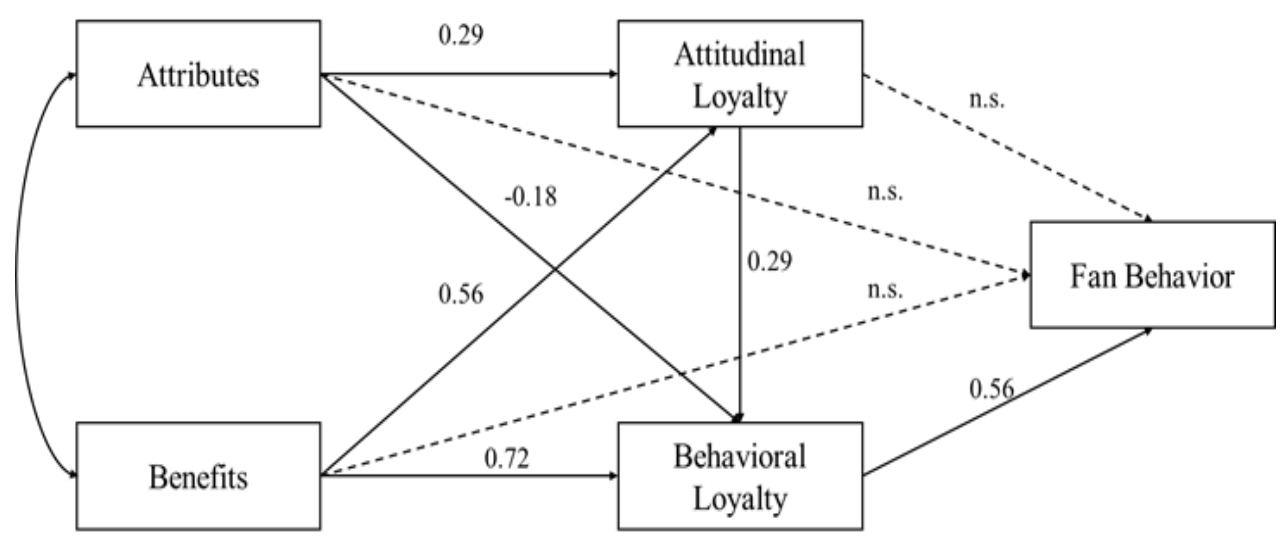

Note: $X^{2} / d f=1.46 . T L I=0.99 . C F I=0.99 . G F I=0.98 . R M S E A=0.030$

Figure 2. Standardized estimates of the structural model with identified path coefficients Sources: developed by the authors.

Overall, the structural model paths performed well. The findings showed that six out of nine hypotheses were supported. The substantial amount of variance for each construct was explained (Table 2).

Table 2. Results of hypothesis tests

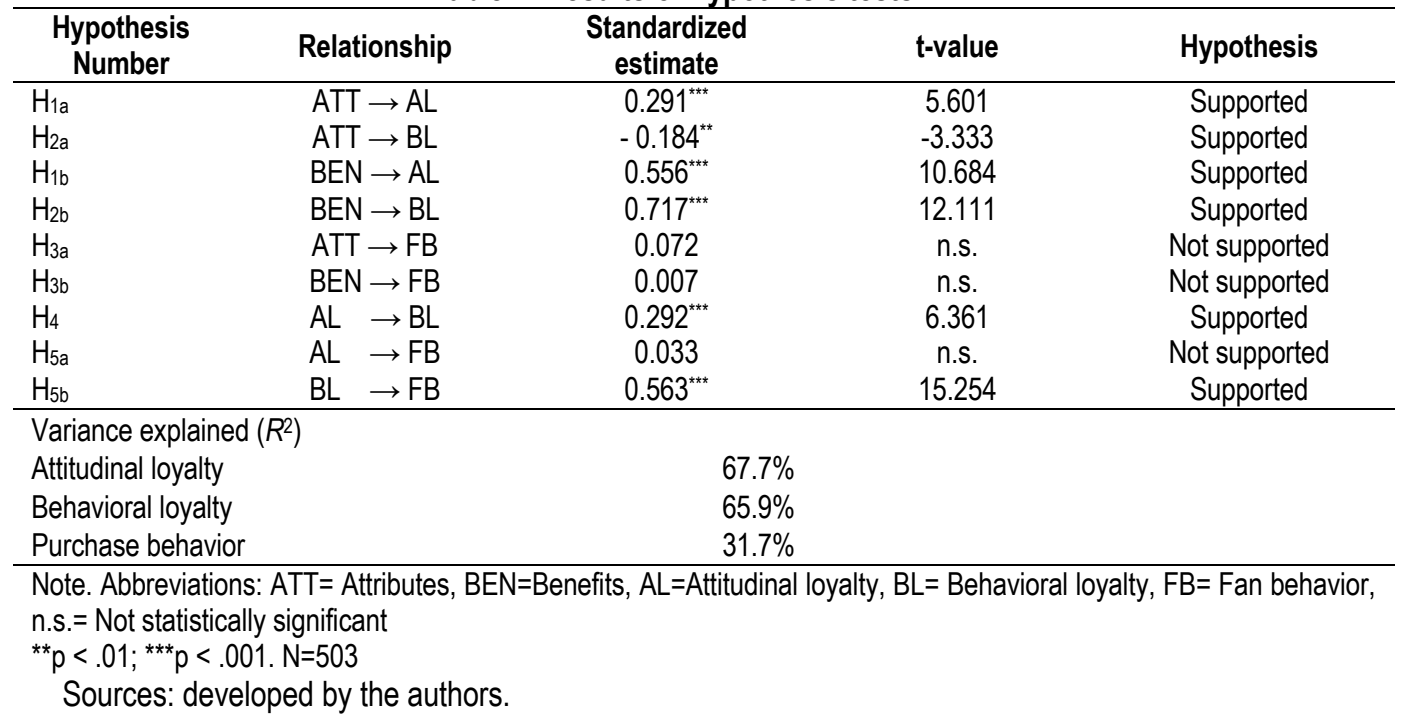

Attributes significantly affected both attitudinal loyalty $(\beta=.291, p<0.001)$ and behavioral loyalty $(\beta=-0.184, p<0.01)$. Thus, $H_{1 a}$ and $H_{2 a}$ hypotheses were accepted. Furthermore, benefits had a positive effect on both attitudinal loyalty $(\beta=0.556 ; p<0.001)$ and behavioral loyalty $(\beta=0.717 ; p<0.001)$. $\mathrm{H} 1 \mathrm{~b}$ and $\mathrm{H} 2 \mathrm{~b}$ hypotheses were supported. However, it was determined that both attributes and benefits on fan behavior did not have a statistically significant effect ( $\beta=0.072 ; p>0.05, \beta=0.007 ; p>0.05$, respectively). Thus, these findings did not support $\mathrm{H}_{3 a}$ and $\mathrm{H}_{3 \mathrm{~b}}$ hypotheses. The examination of relationships between attitudinal and behavioral loyalty showed that attitudinal loyalty positively affected behavioral loyalty 
$(\beta=0.292 ; p<0.001)$. However, attitudinal loyalty did not considerably impact fan behavior $(\beta=0.033$; $\mathrm{p}>0.05)$. Therefore, these findings supported the $\mathrm{H} 4$ hypothesis but not the $\mathrm{H} 5 \mathrm{a}$ hypothesis. The results also confirmed that behavioral loyalty $(\beta=0.563, p<0.001)$ significantly impacted fan behavior. Thus, the $\mathrm{H} 5 \mathrm{~b}$ hypothesis was supported. Finally, the results indicated that approximately $68 \%$ of the variance of attitudinal loyalty could be explained by the attributes and benefits of brand associations' facets $\left(R^{2}=0.677\right)$. Furthermore, facets of the brand associations accounted for approximately $66 \%$ of behavioral loyalty variance $\left(R^{2}=0.659\right)$. Both brand associations (attributes and benefits) and fan loyalty (attitudinal and behavior loyalty) facets explained approximately $32 \%$ of the variance in fan behavior $\left(R^{2}=0.317\right)$.

Conclusions. A better understanding of the appropriate relationship between brand associations and fan loyalty by brand managers is one of the interesting questions today. This study investigated the structural relationships between brand associations, fan loyalty, and fan behavior in Turkish professional football teams. The findings showed that the attributes and benefits did not have a direct effect on fan behavior. Moreover, behavioral loyalty demonstrated a significantly greater effect on fan behavior than on other variables. The findings from this study provided a theoretical contribution, managerial implications, and recommendations for future research. The relationship between brand associations and loyalty is proposed by Keller (2003) and suggested for sports organizations by Ross et al. (2006). Then, Gladden and Funk (2001) and Alexandris et al. (2008) empirically tested this relationship in the sports marketing literature. This study indicated a significant impact of brand associations on fan loyalty. Thus, the findings were consistent with brand associations research in the football industry. The dimensions of team brand associations predicted fan loyalty with a high variance rate. The dimension of the brand association, called the benefits, predicted attitudinal loyalty about two times higher than the dimension of the brand association called attributes. On the other hand, a high proportion of variance in the fans' behavioral loyalty was predicted by the dimensions of the brand associations. However, we determined that the brand association dimension, called attributes, had a negative effect. Gladden and Funk (2001) stated that only three of the eight brand association dimensions associated with attributes are a considerable indicator of brand loyalty (i.e., tradition, product presentation, and star player). Besides, there are negative relationships between two of these dimensions (star player, tradition) and fan loyalty.

On the other hand, as mentioned previously by Yildiz (2016), the dimensions of escape, fan identification, and social interaction demonstrated the benefits concerning individual factors using the sports service. The findings suggested that efforts to develop and maintain long-term brand loyalty could be increased by understanding the role of the supported team in fans' daily lives. Individuals improve their social identity by identifying with specific social groups (Wann, 2006). Besides, they want to move away from daily events by spending time in a social and relaxing environment (Alexandris et al., 2008). In this context, what kind of benefits a football team provides consumers and/or fans should be identified. The evaluation of brand association is a key element to improve appropriate marketing strategies and increase or comprise fans' attitudinal and behavioral loyalty. Keller (2013) noted that «a brand should have strong, preferable and unique brand attributes (explanatory features that characterize a product or service) and brand benefits (the personal value and meaning that consumers add to the product or service features)». The brand attributes characterize a product or service due to descriptive features. The brand benefits are the personal value and meaning that consumers add to their product or service characteristics. According to Gladden and Funk (2001), team management and/or marketers should adopt a customer-oriented focus. Thus, they should perform experience marketing for creating loyal consumers. For this reason, the sports marketing professional should help implement the above conditions with the market communication strategies. On the other hand, the benefits of a product to consumers are divided into three categories according to their basic motivations: functional, symbolic, and experiential benefits in the general marketing literature (Keller, 2013; Park et al., 1986). Future research needs to perform integrative empirical studies that determine the dimensions of functional, symbolic, and experiential benefits 
predicting brand loyalty in professional sports. Attitude change is an important indicator of purchasing behavior, and researchers have suggested that attitudes have causal priority according to behaviors (Fazio et al., 1989). However, Fazio et al. (1989), the positive attitude towards the brand is insufficient to influence consumer behavior. Previous research mentions that team loyalty has significantly affected fans' intentions to watch professional matches at the stadium and on television (Wakefield and Sloan, 1995; Mahony and Moorman, 1999). Therefore, the findings were consistent with the traditional attitude-behavior relationship suggesting that fan loyalty or a favorable positive attitude tends to positive behavior (Fazio et al., 1989). On the other hand, the direct effect of team brand associations on fan behavior results was not significant. The findings showed that the brand associations of the fans promoted fan loyalty, and loyalty had a significant impact on positive fan behavior. Fan loyalty significantly affected fan behaviors. It was described as the frequency of watching the fans in the stadium and on TV, the habits of following the teams in the media, and the behavior of the licensed products in the stadium. Thus, the use of appropriate brand associations could help them appropriately manage their brands to attract or retain fans (Ross et al., 2006). Gladden and Funk (2001) stated that the benefits provided by a sports team to fans should be investigated in more detail. This information would enable the marketing strategies to develop and reinforce team loyalty in highly committed fans (Kerr and Gladden, 2008; Walsh and Ross, 2010). Additionally, sports marketers should focus on obtaining more information about the benefits of following a sports team. In this study, it is necessary to investigate other factors (e.g., age, gender, club membership, brand personality) that may affect fan consumption behaviors in future researches as $31.7 \%$ of the fan behavior was explained. Future studies may benefit from the methodology conducted in explaining and interpreting fan behaviors.

Finally, it stands to note that the obtained data were evaluated within the framework of some constraints. Data were collected from only one city and sports branch (Turkey professional football league). Although our findings are valid for professional football, other amateur football leagues, and other team sports, it is uncertain. The implications from this research could be applied to professional football, other amateur football leagues, and other sports teams. However, further research is needed to explore in detail. Moreover, a high level of loyalty could be examined in this study as this study was conducted in the three most important clubs with the highest fans and significant success in Turkey. For this reason, future studies about the local football fans and other sports branches (e.g., basketball, volleyball, etc.) contribute to the literature. On the other hand, this study could be carried out in a different cultural context. The cross-sectional data approach used in the study may not be the most appropriate approach for identifying fans' processes and mood changes. According to King and Bruner (2000), social desirability bias possibly influences the validity of a multi-item scale survey. Therefore, longitudinal research approaches may be proposed in the studies of fan loyalty (Bauer et al., 2005) to reduce the existing and developmental level of loyalty and the effect of possible changes/fluctuations over time. It may also be advisable to conduct a much shorter questionnaire, which is considered important in implementing a field survey where people may not want to spend a lot of time filling in the questionnaires.

Author Contributions: srepared the outline of the paper, E. E., R. A. and N. S; developed theoretical background and literature review, E. E. and R. A.; provided data and prepared methodology, E. E., R. A. and N. S.; performed the analysis and visualization of results, E. E.; wrote discussion, E. E., R. A. and was responsible for editing and references control, N. S.

Funding: This research received no external funding.

\section{References}

Aaker, D. A., \& Equity, M. B. (1991). The free press. New York, 206. [Google Scholar]

Alexandris, K., Douka, S., Papadopoulos, P., \& Kaltsatou, A. (2008). Testing the role of service quality on the development of brand associations and brand loyalty. Journal of Service Theory and Practice, 18(3), 239. [Google Scholar] [CrossRef] 
Bandyopadhyay, S., \& Martell, M. (2007). Does attitudinal loyalty influence behavioral loyalty? A theoretical and empirical study. Journal of retailing and consumer services, 14(1), 35-44. [Google Scholar] [CrossRef]

Barnard, M., Dwyer, M., Wilson, J., \& Winn, C. (2018). Roar Power. Annual Review of Football Finance 2018. Retrieved from [Link]

Bauer, H. H., Sauer, N. E., \& Schmitt, P. (2005). Customer-based brand equity in the team sport industry: Operationalization and impact on the economic success of sport teams. European Journal of Marketing, 39(5/6), 496. [Google Scholar] [CrossRef]

Bauer, H. H., Stokburger-Sauer, N., \& Exler, S. (2008). Brand Image and Brand Loyalty in Professional Team Sport: A Refined Model and Empirical Assessment. Journal of Sport Management, 22(2), 206-226. [Google Scholar] [CrossRef] BrandFinance. (2020). Brand Finance Football Annual 2020. Retrieved from [Link]

Byrne, B. M. (2010). Structural Equation Modelling with AMOS: Basic Concepts, Applications, and Programming (Multivariate Applications Series). New York: Taylor \& Francis Group. [Google Scholar]

Cobb-Walgren, C. A., \& Donthu, N. (1995). Brand equity, brand preference and purchase intent. Journal of Advertising, 16(03). [Google Scholar] [CrossRef]

Dick, A. S., \& Basu, K. (1994). Customer loyalty: toward an integrated conceptual framework. Journal of the academy of marketing science, 22(2), 99-113. [Google Scholar] [CrossRef]

Farquhar, P. H., \& Equity, M. B. (1989). Marketing research. Marketing research, 1(3), 24-33. [Google Scholar]

Fazio, R. H., Powell, M. C., \& Williams, C. J. (1989). The role of attitude accessibility in the attitude-to-behavior process. Journal of consumer research, 16(3), 280-288. [Google Scholar] [CrossRef]

Funk, D. C., \& James, J. D. (2006). Consumer loyalty: The meaning of attachment in the development of sport team allegiance. Journal of Sport Management, 20(2), 189-217. [Google Scholar] [CrossRef]

Funk, D. C., Filo, K., Beaton, A. A., \& Pritchard, M. (2009). Measuring the Motives of Sport Event Attendance: Bridging the Academic-Practitioner Divide to Understanding Behavior. Sport Marketing Quarterly, 18(3). [Google Scholar]

George, D., \& Mallery, P. (2016). IBM SPSS statistics 26 step by step: A simple guide and reference. Routledge. [Google $\underline{\text { Scholar] }}$

Giroux, M., Pons, F., \& Maltèse, L. (2017). The role of perceived brand personality in promotion effectiveness and brand equity development of professional sports teams. International Journal of Sports Marketing and Sponsorship, 18(2), 180-195. [Google Scholar] [CrossRef]

Gladden, J. M., \& Funk, D. C. (2001). Understanding brand loyalty in professional sport: examining the link between brand associations and brand loyalty. International Journal of Sports Marketing \& Sponsorship, 3(1), 67-95. [Google Scholar] [CrossRef]

Gladden, J. M., \& Funk, D. C. (2002). Developing an understanding of brand associations in team sport: Empirical evidence from consumers of professional sport. Journal of Sport management, 16(1), 54-81. [Google Scholar] [CrossRef]

Gladden, J. M., \& Milne, G. R. (1999). Examining the importance of brand equity in professional sports. Sport Marketing Quarterly, 8, 21-30. [Google Scholar]

Kaynak, E., Salman, G. G., \& Tatoglu, E. (2008). An integrative framework linking brand associations and brand loyalty in professional sports. Journal of Brand Management, 15(5), 336-357. [Google Scholar] [CrossRef]

Keller, K. L. (1993). Conceptualizing, measuring, and managing customer-based brand equity. Journal of marketing, 57(1), 122. [Google Scholar] [CrossRef]

Keller, K. L. (2009). Building strong brands in a modern marketing communications environment. Journal of marketing communications, 15(2-3), 139-155. [Google Scholar] [CrossRef]

Keller, K. L. (2013). Keller: Strategic Brand Management eBook GE 4e. Pearson Higher Ed. [Google Scholar]

Kerr, A. K., \& Gladden, J. M. (2008). Extending the understanding of professional team brand equity to the global marketplace. International Journal of Sport Management and Marketing, 3(1-2), 58-77. [Google Scholar] [CrossRef]

King, M. F., \& Bruner, G. C. (2000). Social desirability bias: A neglected aspect of validity testing. Psychology \& Marketing, 17(2), 79-103. [Google Scholar] [CrossRef]

Kline, R. B. (2015). Principles and practice of structural equation modeling. Guilford publications. [Google Scholar]

Lee, S., Kim, Y., \& Heere, B. (2018). Sport team emotion: Conceptualization, scale development and validation. Sport Management Review, 21(4), 363-376. [Google Scholar] [CrossRef]

Mahony, D. F., \& Moorman, A. M. (1999). The impact of fan attitudes on intentions to watch professional basketball teams on television. Sport Management Review, 2(1), 43-66. [Google Scholar] [CrossRef]

Mahony, D. F., Madrigal, R., \& Howard, D. (2000). Using the psychological commitment to team (PCT) scale to segment sport consumers based on loyalty. Sport marketing quarterly, 9(1). [Google Scholar]

Mullin, B. J., Hardy, S., \& Sutton, W. A. (2007). Sports Marketing. Illinois: Human Kinetics. [Google Scholar]

Oliver, R. L. (1999). Whence consumer loyalty?. Journal of marketing, 63(4_suppl1), 33-44. [Google Scholar] [CrossRef]

Park, C. W., Jaworski, B. J., \& Maclnnis, D. J. (1986). Strategic brand concept-image management. Journal of marketing, 50(4),

135-145. [Google Scholar] [CrossRef]

Ross, S. D., James, J. D., \& Vargas, P. (2006). Development of a scale to measure team brand associations in professional sport. Journal of sport management, 20(2), 260-279. [Google Scholar] [CrossRef]

Srivastava, M., \& Kaul, D. (2016). Exploring the link between customer experience-loyalty-consumer spend. Journal of Retailing and Consumer Services, 31, 277-286. [Google Scholar] [CrossRef] 
Su, J., \& Tong, X. (2015). Brand personality and brand equity: evidence from the sportswear industry. The Journal of Product and Brand Management, 24(2), 124. [Google Scholar] [CrossRef]

Tabachnick, B. G., \& Fidell, L. S. (2007). Using Multivariate Statistics. Massachusetts: Allyn \& Bacon. [Google Scholar]

The Business Research Company. (2019). Global Sports Market Opportunities and Strategies. Retrieved from [Link]

The Business Research Company. (2020). Sports Global Market Report 2020-30: COVID-19 Impact and Recovery. Retrieved from [Link]

Wakefield, K. L., \& Sloan, H. J. (1995). The effects of team loyalty and selected stadium factors on spectator attendance. Journal of sport management, 9(2), 153-172. [Google Scholar] [CrossRef]

Walsh, P., \& Ross, S. D. (2010). Examining Brand Extensions and Their Potential to Dilute Team Brand Associations. Sport Marketing Quarterly, 19(4). [Google Scholar]

Wann, D. L. (2006). Understanding the positive social psychological benefits of sport team identification: The team identificationsocial psychological health model. Group Dynamics: Theory, Research, and Practice, 10(4), 272. [Google Scholar] [CrossRef]

Yildiz, Y. (2016). A research on soccer teams' brand associations. The Sport Journal, 19. [Google Scholar]

Ерсін Ескілер, доцент, Університет прикладних наук Сакар'я, Туреччина

Ремзі Алтунісік, професор, Університет Сакар'я, Туреччина

Нілгун Сарікая, професор, Університет Сакар'я, Туреччина

Оцінювання взаємозв'язку між асоціаціями про бренд серед прихильників футбольних команд та їх поведінкою

Нарощування конкуренції у сфрері спорту обумовила трансформацію сприйняття менеджментом футбольних команд ролі та значення спортивного маркетингу. Авторами зазначено, що менеджмент спортивних клубів повинен фокусуватись на формуванні позитивного бренду свого клубу, підвищенні рівня лояльності до нього серед прихильників, а також на створенні емоційного звязку між брендом клубу та його прихильниками. Своєю чергою, це забезпечить отримання додаткових конкурентних переваг для футбольного клубу. Метою даного дослідження $є$ оцінювання взаємозв'язків між споживачами та брендом, лояльністю прихильників до футбольних команд та їх поведінкою. Детерміновану вибірку даних сформовано на основі результатів опитування 503 респондентів (293 чоловічої статі та 210 жіночої статі). Об'єктом дослідження є прихильники спортивних клубів «Besiktas Gymnastics Club», «Fenerbahce Sports Club» та «Galatasaray Sports Club». Для перевірки висунутих гіпотез дослідження застосовано моделювання структурних рівнянь. Отримані результати свідчать про відсутність статистично значущого зв'язку між асоціаціями про бренд спортивних команд та поведінкою його прихильників. При цьому асоціації про бренд мали значний статистично значущий вплив на рівень лояльності прихильників футбольних клубів. Авторами відмічено, що рівень лояльності $є$ важливою детермінантою поведінки вболівальників. За результатами дослідження встановлено, що близько 68\% відмінностей у рівнях лояльності прихильників футбольних клубів залежать від зміни асоціацій про бренд ( $R 2=0.677)$. Натомість зміна асоціацій про бренд пояснюється на $66 \%$ відмінностями у рівнях лояльності футбольних прихильників (R2 = 0.659). Зміни в асоціаціях про бренд та рівнях лояльність прихильників пояснюють близько $32 \%$ відмінностей у поведінці прихильників $(\mathrm{R} 2=0.317)$. Таким чином, авторами зроблено висновок про необхідність формування сильних та конкурентоспроможних асоціацій серед прихильників про бренд футбольних команд, незалежно від спортивних досягнень. Результати дослідження можуть бути корисними спортивним менеджерам/маркетологам, а також теоретикам для пояснення та інтерпретації поведінки прихильників.

Ключові слова: асоціації бренду, лояльність, поведінка, прихильники, футбольні клуби. 